\title{
Clinical Trial Site Management Filenote
}

National Cancer Institute

\section{Source}

National Cancer Institute. Clinical Trial Site Management Filenote. NCI Thesaurus. Code C115549.

A notation that describes any decisions or clarifications of information pertaining to the site management of a clinical trial. 